\title{
Modified Reciprocal Teaching: Cooperative Learning Technique for Enhancing Communication Skills of First Year Engineering Students
}

\author{
Ms. Dipali M. Kadam ${ }^{1}$, Ms. Supriya Y. Sawant ${ }^{2}$ \\ ${ }^{1}$ Sciences and Humanities Department, Rajarambapu Institute of Technology, Rajaramnagar, Affiliated to Shivaji University, \\ Maharashtra, \\ ${ }^{2}$ Automobile Engineering Department, Rajarambapu Institute of Technology, Rajaramnagar, Affiliated to Shivaji University, \\ Maharashtra, \\ 1dipali.kadam@ritindia.edu \\ ${ }^{2}$ supriya.sawant@ ritindia.edu
}

\begin{abstract}
With the advancement of technology and globalization, Communication skills as a life-long learning skill is an essential component in engineering education. Communication is one of 12 graduate attributes, defined by ABET (Accreditation Board for Engineering and Technology). The engineering classroom is currently experiencing a shift from teacher-centred teaching where teacher focused on what they are teaching, to studentcentred learning through innovative teaching-learning techniques. Active learning has become a significant process in outcome-based education (OBE). It comprises various approaches such as cooperative and collaborative learning techniques, PBL (problem/project/puzzle-based Learning), TBL (Task based learning), Peer instructions, TP-S (Think- Pair- Share), Flipped Classroom and Reciprocal Teaching and many others.

The Reciprocal Teaching is an instructional strategy specially designed for comprehension purpose. The present work offers some insights after successful implementation of modified reciprocal teaching for improving communication skills of First Year B. Tech. students at Kasegaon Education Society's Rajarambapu Institute of Technology, Rajaramnagar (RIT). It was an attempt to develop all four basic language skills: Listening, Speaking, Reading and Writing. This research was conducted for four weeks during practical sessions. After successful implementation the students of experimental group were assessed by qualitative and quantitative methods. The results reflected increase in $\mathrm{CO}$ attainment of experimental group as compared to control group. The structured implementation of modified reciprocal teaching as an active learning tool helped to enhance students' presentation skills, team work, leadership skills, and ultimately communication skills.
\end{abstract}

Keywords: Communication, Life-long learning, Active learning, Cooperative learning, $\mathrm{OBE}$

\section{Corresponding Author}

Ms. D. M. Kadam, Department of Sciences \& Humanities, Rajarambapu Institute of Technology, Rajaramnagar dipali.kadam@ritindia.edu

\section{Introduction}

Today we are living in competitive world, where success in carrier depend not just on acquiring knowledge and domain specific skills, but also on effective communication skills. Communication has left no field untouched: be it law, fine arts, basic sciences, medical or engineering. English is cited as the ...major language of international business, diplomacy, and science and the professions [1]. For engineering students to be employable, communication in English language is the major requirement. It is the biggest determiner of success in the modern engineer's professional career. The incorporation of language and communication improvement courses is an important element of continuous learning, and will ultimately contribute to the process of life-long learning [2]. RIT introduced English Proficiency Lab I\&II courses for F. Y. B. Tech students to foster communication skills in English language. The objective of implementation of these courses at entry level is to enhance four basic English language skills viz. listening, speaking, reading and writing. The course has been designed by keeping following course outcomes at centre.

After successful completion of the course student will be able: 
1. To demonstrate listening skill through comprehension by applying the skills and strategies of active listening.

2. To comprehend reading content with competency by applying reading techniques.

3. To prepare and communicate desired message through letters and reports in appropriate formats

4. To demonstrate verbal and non-verbal communication ability through presentations, speeches, group discussion, role plays.

In order to achieve these course outcomes various active learning methods like T-P-S, puzzle-based learning, project-based-learning, jigsaw, brainstorming session, role plays, mobile assisted language learning and cooperative learning methods are being used. This research work narrates successful implementation of modified reciprocal teaching for the above said class.

\subsection{Reciprocal Teaching as a Cooperative Learning Technique}

Cooperative learning is an instructional strategy which develops positive interdependence and creates learning environment in classroom. It helps to promote higher order cognitive skills among students. Reciprocal teaching is one of the cooperative learning techniques, was developed by Palincsar and Brown in 1984. It facilitates a group effort between teacher and students as well as among students in the task of bringing meaning to the text [3]. It has roots on Vygotsky's theory about the role of social interaction in the development of cognition [4]. This technique promotes thinking while reading, resulting in better comprehension of the reading material. Cooperative learning, group discussion and dialogue were all beneficial during the reciprocal teaching procedure $[5,6]$. The delivery of the instruction can take a variety of approaches but usually incorporates scaffolding, small groups and the teaching of four reading strategies: Generating questions, summarizing, clarification and prediction [7].

Conventional reciprocal teaching focuses on reading comprehensions only. The aim of reciprocal teaching is to use discussion to improve students' reading comprehension, develop self-regulatory and monitoring skills, and achieve overall improvement in motivation [6].

Many researchers agree that reciprocal teaching can be incorporated in other content areas $[7,8]$. The present work reflected the same with different perspective. For engineering students beyond reading skills there is requirement of developing presentations skills and interpersonal skills. By considering this the researcher modified the conventional reciprocal teaching. The difference between conventional and modified reciprocal teaching is shown in Fig. 1.

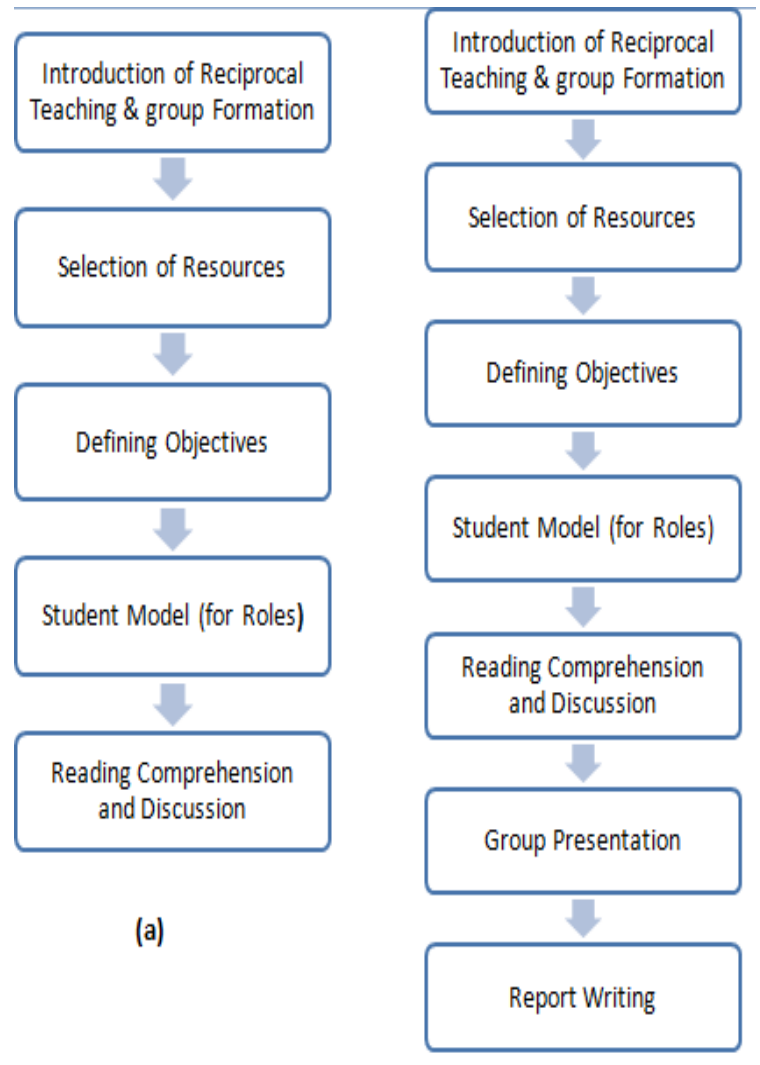

(b)

Fig. 1 Difference between a) Conventional Reciprocal Teaching

Method and b) Modified Reciprocal Teaching Method

The reading material selected for this activity is from technical domain so that students can learn any technical course by this method at their own and experience peer learning. This activity fosters relationships between students [8]. After successful discussion of the content as per defined roles, group presentations were conducted on given reading material and students were asked to write detail report of their whole group activity as shown in Fig. 1. Due to these add on presentation and report writing tasks students were actively interacted with each other which helped them to develop interpersonal skills and team work. The whole activity was assessed by using rubrics which covered reading skill, summarizing skills, listening skill, presentation skills and report writing skills.

\section{Methodology}

The experimental group selected for implementation is of 32 students from First Year B. Tech Civil engineering $\mathrm{C} 2$ batch while Control group is of 35 students of $\mathrm{C} 1$ batch. The course was delivered to both groups by same instructor. The instructor has intentionally delivered course to control group by conventional teaching method.

The activity was implemented to experimental group as per following stages:

1. Introduction and instructions about the modified reciprocal teaching activity

2. Formation of group of students: 
3. Defining role of individual student by students only like predictor, questioner, clarifier and summariser.

4. Providing resource Material for reading to groups

5. Time allotment for reading- 20 Minutes

6. Execution of individual's role

7. Summary writing as per the roles defined

8. Group presentations by all groups

9. $\quad$ Report writing

This sequence was followed for 4 sessions, for 4 different topics and the role of individual student shifted as shown in figure 2 . The instructor acted as a facilitator and evaluator.

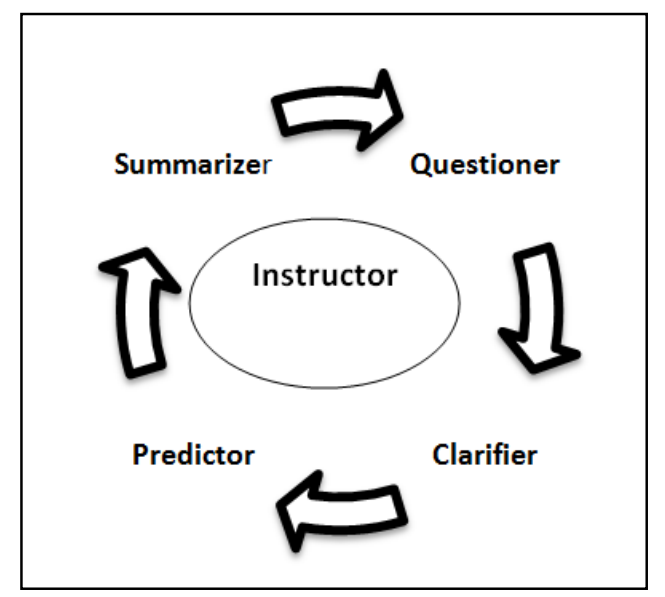

Figure.2 Shifting of role of students in Modified reciprocal teaching method

Total 8 groups were actively involved to discuss the topics related to Green Technology during these sessions. The understanding of topic was evaluated during the session by the instructor with the help of previously defined rubrics. Each participant in a group got chance to be a leader and managed group work by discussion through the four main strategies. The students had great level of brainstorming for particular topic. The group presentations were conducted on assigned topic from selected topics. The presentations were followed by question-answer session and discussion on observations. The groups showed enthusiasm and team spirit to clear the doubts raised by peers. The presentations were recorded for improvement in presentation skills. At the end students wrote the report of the task as per the instructions received from instructor. The purpose of writing report is to assess basic grammar, vocabulary and presentation styles.

\subsection{Assessment}

To investigate the effects of modified reciprocal teaching on first year engineering students, and whether this method enhanced participants' performance as per the objective of activity both qualitative and quantitative assessments were done. The qualitative assessment was carried out by using already defined and published holistic rubrics. The parameters of rubrics were preparedness and active participation, listening and response, reading comprehension and summarizing, communication and presentation and writing skill. The assessment through rubrics focused on students 'role performing and active participation, demonstration of active listening skills by providing thoughtful responses, including asking questions, speaking, body language, no grammatical errors, correct pronunciation, clarity in writing as per the task and convincing evidence to support main idea. The students were assessed at 4 levels: level1, 2, $3 \& 4$ respectively in descending order.

Quantitative assessment was done by using rating method in which the researcher provided questionnaire to students having 5 statements and students were assessed the activity by choosing one option as shown in Table 1 . The sixth point is for any observations. The observations recorded by students were analysed for future implementation.

Table 1. Rating Method

\begin{tabular}{|c|c|c|c|c|c|c|}
\hline $\begin{array}{l}\mathbf{S} \\
\mathbf{r}\end{array}$ & Statement & $\begin{array}{l}\text { Stron } \\
\text { gly } \\
\text { agree }\end{array}$ & $\begin{array}{l}\text { A } \\
\text { gr } \\
\text { ee }\end{array}$ & $\begin{array}{l}N \\
\text { eu } \\
\text { tr } \\
\text { al }\end{array}$ & $\begin{array}{l}\text { Di } \\
\text { sa } \\
\text { gr } \\
\text { ee }\end{array}$ & $\begin{array}{l}\text { Stron } \\
\text { gly } \\
\text { disag } \\
\text { ree }\end{array}$ \\
\hline 1 & $\begin{array}{l}\text { The technique } \\
\text { helped to keep you } \\
\text { engaged during } \\
\text { the practical and } \\
\text { promoted learning } \\
\text { efficiency }\end{array}$ & & & & & \\
\hline 2 & $\begin{array}{l}\text { The technique } \\
\text { gave you chances } \\
\text { to interact with } \\
\text { your peers and } \\
\text { promote peer } \\
\text { learning and } \\
\text { enhancement in } \\
\text { interpersonal } \\
\text { communication } \\
\text { skills. }\end{array}$ & & & & & \\
\hline 3 & $\begin{array}{l}\text { The proper } \\
\text { motivation has } \\
\text { given you } \\
\text { opportunity to } \\
\text { work in teams and } \\
\text { build leadership } \\
\text { skills also. }\end{array}$ & & & & & \\
\hline 4 & $\begin{array}{l}\text { Improvement in } \\
\text { language } \\
\text { competencies in } \\
\text { the form of LSRW } \\
\text { skills }\end{array}$ & & & & & \\
\hline 5 & $\begin{array}{l}\text { Do you feel such } \\
\text { type of active } \\
\text { learning } \\
\text { techniques helped } \\
\text { more to enhance } \\
\text { skills than } \\
\text { traditional } \\
\text { teaching method }\end{array}$ & & & & & \\
\hline
\end{tabular}




\begin{tabular}{|l|l|l|}
\hline 6 & $\begin{array}{l}\text { Other } \\
\text { observations }\end{array}$ & \\
\hline
\end{tabular}

\section{Results and Discussion}

Fig. 3 shows graphical comparison of $\mathrm{CO}$ attainment of experimental group and control group. Each Course outcome is evaluated for 25 marks. Experimental group has obtained average 20 marks while control group has obtained average 16 marks.

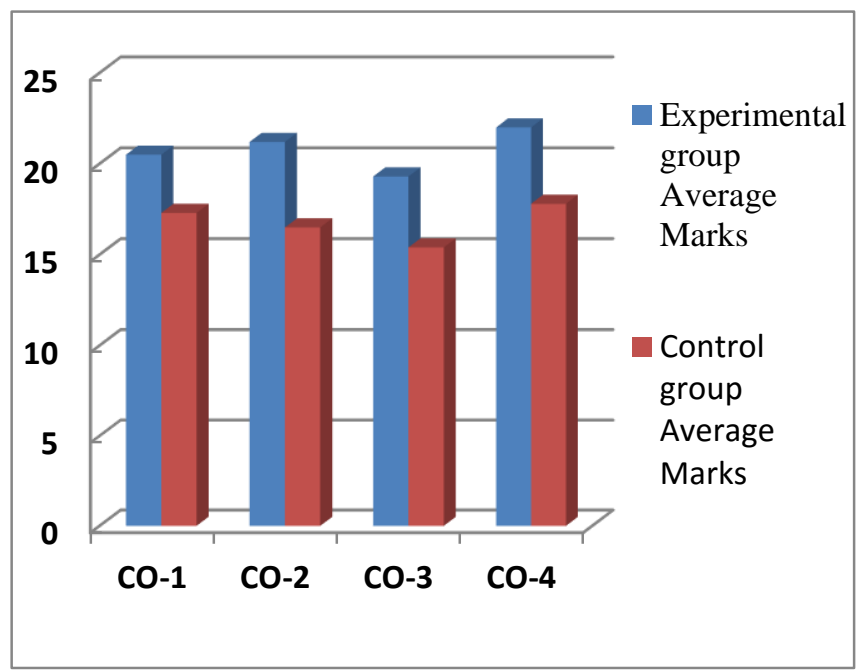

Fig.3 Comparison of Co attainment by direct assessment

Method.

The average increment in marks of experimental group is $16 \%$ which is significant. The most appreciable thing is that the attainment of course outcome 4 which is related to presentation skills (the major requirement from engineering students) is the highest in all other course outcomes.

For quantitative assessment rating method was used. Students were provided questionnaire having 5 questions for rating purpose. A completely anonymous survey was conducted to obtain students' feedback. Figure 4 shows that $70 \%$ students were strongly agreed with the affirmative statements of achievements of outcomes of activity.

\section{Modified Reciprocal Teaching Analysis}

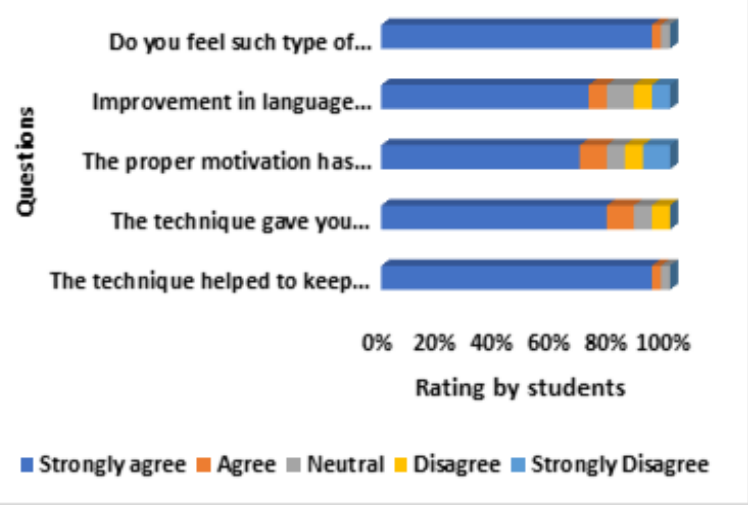

Fig. 4 Result analysis of rating method

The observations from qualitative and quantitative assessment are given below:

1. Students' confidence level is enhanced due to peer learning.

2. Students 'became active listeners as they actively involved in discussions.

3. The students who were shy tried their level best to overcome the shyness while giving presentations.

4. Fear of teacher was reduced as role of teacher was the mentor and motivator.

5. The comprehension skills were enhanced.

6. The presentation skills (verbal \& non-verbal modes) were improved.

7. Overall performance of students was better as compared to traditional teaching of reading.

\section{Conclusion}

Good communication skills in English language are very important in the education of engineering students to prepare them for the demanding and competitive job market. Modified reciprocal teaching is a cooperative learning approach which focused on four basic English language skills. As per the observations, it could be seen that this strategy helped students to understand given text easily as they performed the roles of predictor, questioner, clarifier and summarizer well. It means by using this strategy the students understood the content of the text given by the teacher. The students' involvement made it sure that they are responsible for learning. The data from questionnaire showed that the implementation of strategy for reading comprehension enhances students' listening, writing, reading and presentations skills. The performance of the experimental group has been increased by average $16 \%$ in the form of $\mathrm{CO}$ attainment. The effectiveness of the evaluation using direct and indirect method has shown increase in the performance of experimental group. This activity also explores team work, leadership and selfmanagement skills through peer learning. 


\section{Acknowledgement}

The authors wish to express thanks to Dr. Mrs. Sushma S. Kulkarni, Director, Rajarambapu Institute of Technology Rajaramnagar for her encouragement and continuous support for this research work.

\section{References}

1. Kitao, K., (1996). Why do we teach English? The Internet TESL Journal, Vol. II, No. 4. http://iteslj.org/Articles/Kitao

2. Riemer, Marc J. (2007). Communication Skills for the 21 st Century Engineer, Global J. of Engng. Educ., Vol.11, No.1.

http://www.wiete.com.au/journals/GJEE/Publish/ voll1nol/Riemer.pdf

3. Palincsar, A.S. (1986). Reciprocal teaching. In Teaching reading as thinking. Oak Brook, IL: North Central Regional Educational Laboratory

4. Vygotsky, L.S. (1978). Mind in Society: The development of the higher psychological processes. Cambridge, MA: Harvard University Press.

5. King, C., \& Johnson, L. (1999). Constructing meaning via reciprocal teaching. Reading Research and Instruction, 38 (3), 169 - 186.

6. Allen, S. (2003). An analytic comparison of three models of reading strategy instruction. International Review of Applied Linguistics in Language, 41 (4), 319 - 339.

7. Alfassi, M., (1998). Reading for meaning: The efficacy of reciprocal teaching in fostering reading comprehension in high school students in remedial reading classes. American Educational Research Journal, 35(2): 309-332.

8. Hashey, M. \& Connors, D. (2003). Learn from our journey: Reciprocal teaching action research. The Reading Teacher, 57 (3), $224-232$. 